\title{
Vegetation Mapping of the Mond Protected Area of Bushehr Province (SW Iran)
}

\author{
Ahmadreza Mehrabian*1, Abdolrassoul Salman Mahiny, \\ Hossein Mostafavi ${ }^{1}$ and Homan Liaghati ${ }^{4}$ \\ ${ }^{1}$ Department of Botany, Faculty of Biological Sciences, Shahid Beheshti University, \\ Tehran, Iran \\ ${ }^{2}$ College of the Environment, Gorgan University of Agriculture and Natural \\ Resources Sciences, Iran \\ ${ }^{3}$ Department of environmental and resources economic, Environmental Sciences Research \\ Institute, Shahid Beheshti University, Tehran, Iran \\ ${ }^{4}$ Department of Biodiversity and Ecosystem Management, Environmental Sciences \\ Research Institute, Shahid Beheshti University, Tehran, Iran
}

\section{Introduction}

Ecosystems dominated by natural and semi-natural vegetation, occupy large portions of the Earth's surface and provide important services that should be preserved (Balvanera et al., 2001). Vegetation mapping is one of the most important phases of vegetation conservation. Satellite data such as those produced by Landsat and Spot have became ever more available to the public (Mahiny 2004) and advances in the automatic classification of satellite data make this technique an important tool for vegetation mapping nowadays (Jenes, 1996). The main goal of traditional vegetation mapping has been the identification of plant communities which are defined as the repetitive combination of species, structural types, growth forms and other terrain attributes (e.g. McGraw and Tueller, 1983; Wallens et al., 2000; Calarck et al., 2001; Zak and Cabido, 2002; Tobler et al., 2003). The mixing of traditional and advance methods can be used for comprehensive studies in the vegetation mapping. Due to the vulnerability of arid regions, comprehensive vegetation studies are necessary in these areas. The arid regions of the world occupy 26-35 percent of the earth's land surface, much of this wide region lying latitudes of between 15 and 30 degrees Northern and reflects various types based on the climatic conditions (Archibold, 1995). There is a shortage of knowledge on the vegetation of the Middle East, but investigations have been carried out on the ecology of individual plants and their associations (Zohary, 1973). The coastlines in the Middle East can support a diverse range of flowering plants; some are tolerant to highly saline soil and inundation to various degrees, while others inhabit low salinity soil. Regional climatic, topographic and geographic conditions are assumed to be the main causes of vegetation forming in the desert and semi desert areas of Iran (Zohary, 1966-1986). In the hot southern parts of Iran with relatively high temperatures in both winter and summer and scant rainfall, a climatic regime governs which is similar to 
that of tropical northeast Africa, and the hot Sindian desert dominates, with occasionally more server temperature maxima and minima (Rechinger, 1963-1999; Zohary, 1966-1986 and Assadi, 1984). Iran is the classic country of great salines and Kavirs; Saline and alkaline soils are expanding in arid and semi-arid regions and cover $12.5 \%$ of the total land area of the country. These include Solenchak and Solontez soils, salt marsh soils, desert soils, Sierozem mixed with Solenchalk soils and saline alluvial soils (Dewan \& Famouri, 1964). The elevation of the regions varies between $-28 \mathrm{~m}$ on the shores of the Caspian Sea to about 1650 $\mathrm{m}$ in Kavire-Meyghan, Markazi Province (Akhani \& Ghorbanli, 1993). Halophytic communities in Iran have been studied by many researchers. Zarinkafshe (1977) studied salty regions of Iran for flora, while Kunkel (1977) addressed the plants in the Hormoz, Qeshm and neighbouring islands. Moreover, some investigations have been carried out on the plants and vegetation of the Qeshm and Kish Island, the Persian Gulf region was also studied by Termeh \& Moussavi (1982), Hamzehée (2001) and Attar et al. (2004).

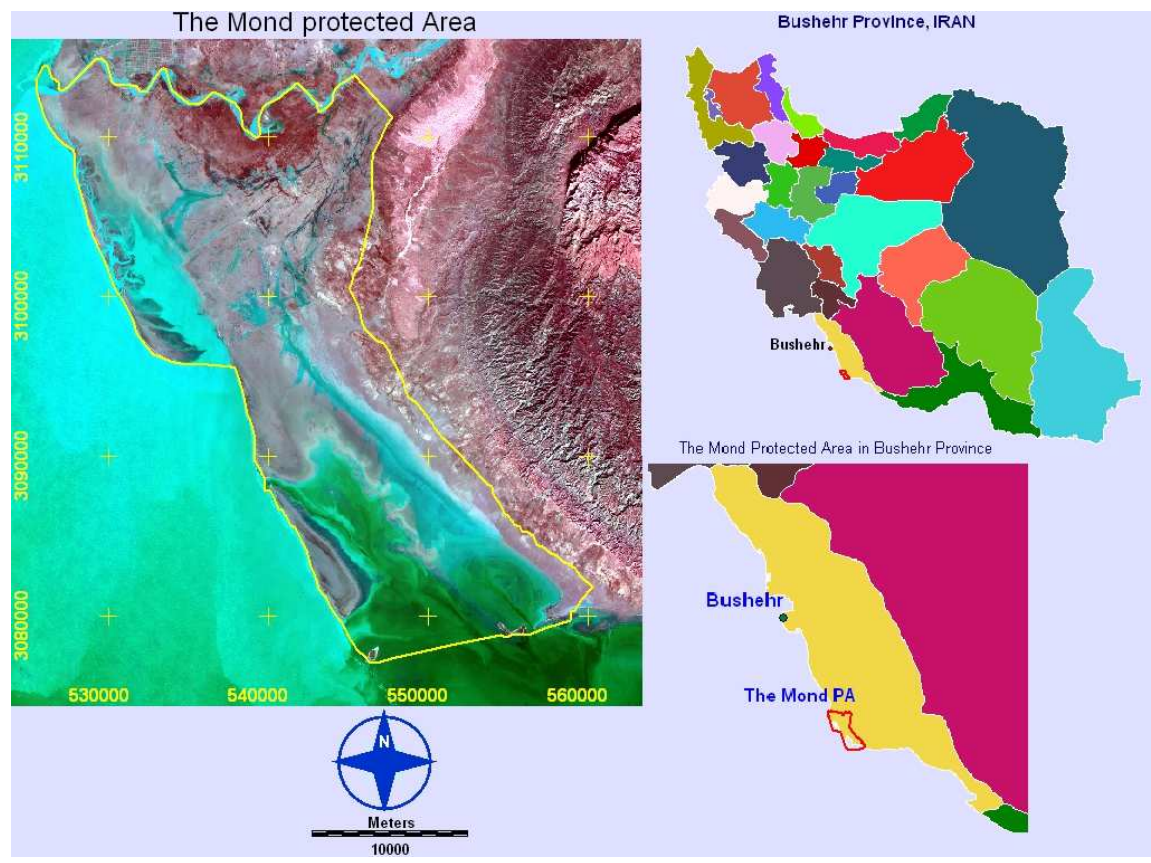

Fig. 1. Location of the Mond Protected Area in the coastal zone of Persian Gulf, Southern Iran.

The distribution of halophytic communities has been depicted cartographically by Mobayen \& Tregubov (1970), Mobayen (1976), Freitag (1977), Carle and Frey (1977), Frey (1982), and Kramer (1984). Further physiognomic and ecological-geographic data on such plant communities have been provided by Kunkel (1977), Ghorbanli and Lambinon (1978), Breckle (1983), Assadi (1984), Frey and Probst (1986), and Akhani and Ghorbanli (1993). Many researchers have been carried out on salt desert vegetation e.g., Zohary $(1963,1973)$, Termeh and Moussavi (1976), Leonard (1981-1988), Asri et al. (1995) and Asri and Ghorbanli (1997), Mehrabian et al., 2008). Due to the ecological and conservational values of Mond 
Protected area (Bushehr Province, Iran), this area was selected for vegetation mapping based on an integrative description of community structure and floristic attributes. The most important goals of this paper are 1) to provide a case of vegetation type mapping in the arid study area using field work, GIS and RS techniques, and 2) to compare these results with those other arid regions of the world.

\section{Important}

Mond Protected Area covers 53227 hectares and is located to the southwest of Bushehr between Northern latitude $27^{\circ} 15^{\prime}$ to $28^{\circ} 45^{\prime}$ and Eastern longitude $51^{\circ} 15^{\prime}$ to $51^{\circ} 35^{\prime}$ (Fig. 1 ). The average yearly temperature is $140 \mathrm{C}$ and annual precipitation is $155 \mathrm{~mm}$. The study area is very flat, with its highest altitude at only $12 \mathrm{~m}$. There are three physiographical units in the area including alluvial and colluvial fans, river alluvial plains and lowlands. The soils consist of alluvial, regosols, saline alkaline soils, solonchak and solontez. Administratively, tree islands called Omolgorm, Tahmadoon and Nakhiloo have been included in the area. Soils of the islands belong to the saline-alkaline type with a sandy texture (Fig. 2). The Mond area can be phytogeographically classified within the Sahara-Sindian region (Leonard, 19811988). However, it can also be classified in the Sudanian region (sensu Zohary, 1973).

Vegetation sampling was carried out during 2005 to 2007 when the soils and vegetation map units were studied. We used all four bands of the Spot5 Satellite XS imagery acquired on 26 January 2005 to investigate the vegetation attributes. Image projection was WGS 84, and the zone number was 39n. Unsupervised classification was conducted and sampling units were chosen for the field work. Owing to the sparse vegetation of the area and based on a visual examination of the image, we found that a combined visual, unsupervised and supervised method should be used for vegetation mapping of the area. For visual assessment, we generated a pseudo-color composite image using bands 2, 3 and 4 of the Spot5 imagery. We also used bands 2 and 4 to produce a preliminary NDVI layer (Normalized Difference Vegetation Index) showing crude vegetation density for the area. This was used along with unsupervised map and other ancillary data to sample vegetation in the field. Vegetation sampling was conducted following Braun-Blanquet cover scale (Braun-Balnquet, 1964). We used 156 geographically positioned sampling points to assess vegetation. The size of samples varied between $4 \mathrm{~m} 2$ to $32 \mathrm{~m} 2$ based on the minimal area taken at each point. The field work and satellite images were mutually complementary. Dominant and companion species and their coverage were recorded in samples. Vegetation types for each area were recognized according to the occurrence of specific perennial species accompanied by some companion species. These dominant species were used for naming each vegetation type. Species emerging in each season were added to the plant list of each vegetation type during the investigations. Geo-positioning of sampling points made using with GPS The visual boundary of the map units was digitized and stored on GIS for future analysis. Using data gathered on the field, unsupervised classification of the Spot5 XS bands through is cluster module of the Erdas Imagine 8.4 software (Leica Geosystems Geospatial Imaging) and visual examination of the pseudo-color composite of the area, we distinguished different vegetation types (as map units on the GIS map) delineated them on the image and produced a final vegetation map. Vegetation map units are defined as areas where vegetation is relatively homogenous (Samira et al., 2001). A map unit is defined and named according to the taxonomic classification of the dominant community. Each map unit for the area 
comprised a vegetation type with the exception of those areas empty of vegetation. Water bodies and bare lands. Information about soils in the study area is based on previous soil studies in different parts of the area. Based on these studies, four major types of soil were recognized which can be subdivided to 13 detailed soil units (Fig. 2). Moreover, a classification of the habitats in the study area was provided according to fieldworks and complementary GIS methods which helped in vegetation type mapping.

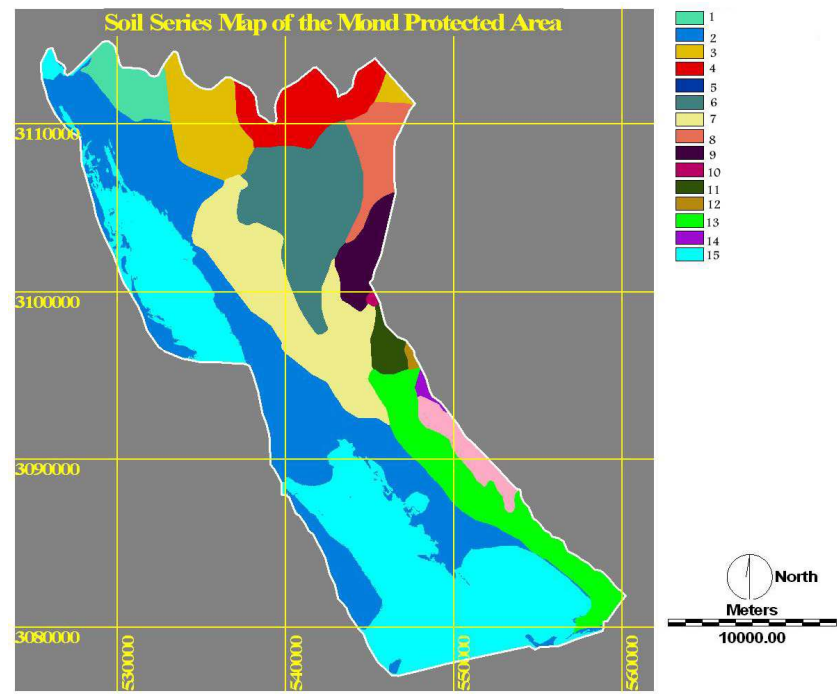

Fig. 2. Soil map of the Mond Protected Area. (1,3,4,13=Alluvial 2, 7, 8,10,11, 12 14=Solenchak 9=Regosoil, 15=Water. Different number represent gradient in each one.

Based on field observation and supported by satellite maps, three major habitat zones in the study area i.e. coastal zone, riverine zone and inland zone were recognized. These habitat zones are covered with three broad plant formations in the area. These are shrublands (northern parts), bushy grasslands (inland parts) and mangrove forests (southeastern parts of the coastal zone). In each formation, different vegetation types were recognized on the basis of field vegetation sampling guided by an unsupervised classification of the Spot XS data. Twelve vegetation types were recognized in the field that showed a good compatibility with the satellite image (map units). Moreover, large parts of the study area near the sea coast were bare lands or filled by sea water. These parts together with cultivated areas were defined as separate map units on the final map manipulated by GIS (Fig. 3). The vegetation types were variable in size and flora composition. Some vegetation types covered more than $20 \%$ of the area while others had coverage of less than $5 \%$ (Table 1 ). Some vegetation types, e.g. Halocnemum strobilaceum, Suaeda aegyptiaca, Lycium edgworthii are widely distributed, but Ephedra foliata (Nakhiloo island), Salsola drummundi (Eastern area), Atriplex leucoclada (Nakhiloo island), Salicornia europaea-Suaeda heterophylla (northwestern area) and Avicennia marina (south eastern area) are restricted to small habitats (Fig. 3). There are three vegetation types (Arthrocnemum macrostachyum, Ephedra foliata and Cyperus conglomerates-Halopyrum mucronatum) on Omolgorm Island, two vegetation types (Arthrocnemum macrastachyum and Cyperus conglomerates-Halopyrum 
mucronatum) on Tahmadoon Island and three vegetation types (Arthrocnemum macrostachyum, Cyperus conglomerates-Halopyrum mucronatum and Atriplex leucoclada on Nakhiloo Island (Fig. 3). The density of vegetation was presented as a map using bands 2 and 4 of the Spot XS data in NDVI calculation. The density indicated an increase in vegetation southward to northward and westward to eastward (Fig. 4).

\section{A-Shrubland formation (along the Mond River)}

\section{1-Tamarix leptopetala-Phragmites australis vegetation type (no. 16 in Fig. 3)}

Tamarix leptopetala Bge. and Phragmites australis (Cav.) Trin. ex Steud are two dominant species of this vegetation type. Phragmites australis is a hygrophilous plant in rivers and saline marshes (Asri and Ghorbanli 1997). Tamarix leptopetala is one of the most characteristic genera in the Middle East (Zohary 1973). It comprises of about 35 species in the Middle East, many occurring in saline habitats, saline river beds and desert wadies, saline and sandy soils, estuaries of central depressions and vast areas of inland salines with a relatively high water table (Zohary 1973).

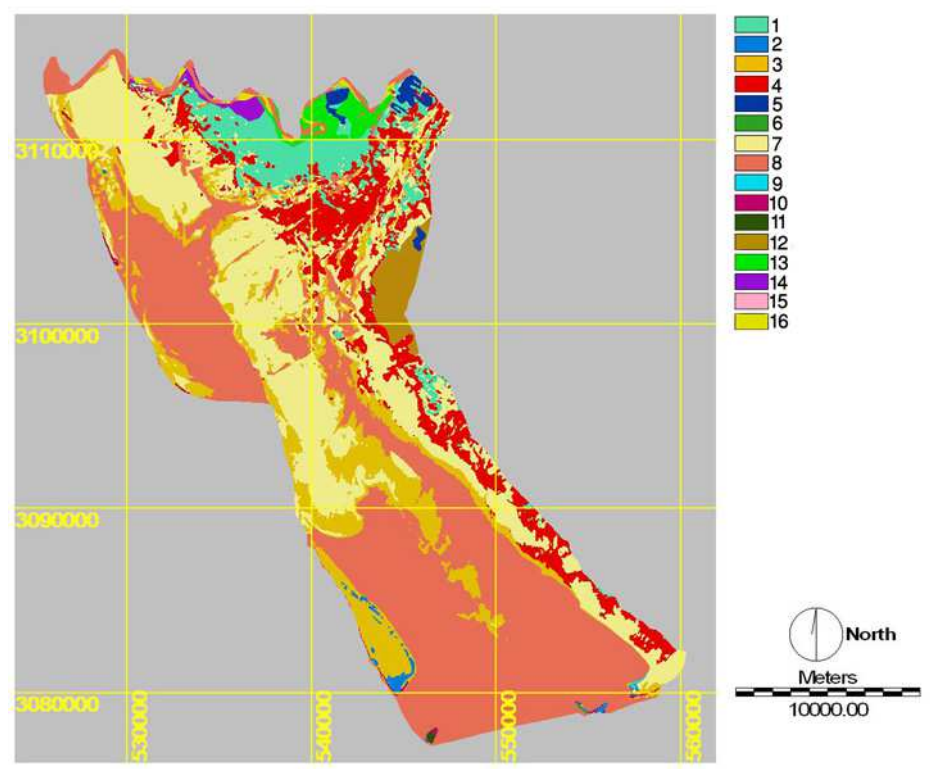

Fig. 3. Vegetation types and map units in the Mond Protected Area (Zohary, 1973): 1Suaeda aegyptiaca, 2- Arthrocnemum macrastachyum, 3- Bare lands, 4- Halocnemum strobilaceum ((high density), 5- Farmlands, 6- Halocnemum strobilaceum (low density), 7Water, 8- Avicennia marina, 9- Cyperus conglomerates-Halopyrum mucronatum, 10Atriplex leucoclada, 11- Salsola drummondii, 12- Lycium edgworthii, 13- Suaeda fruticosa, 14- Salicornia europaeae- suaeda heterophylla, 15- Tamarix leptopetala

The Tamarix leptopetala- Phragmites australis vegetation type is situated in the banks of the Mond River. The first zone of this riverine vegetation belt comprises Phragmites australis and towards the inland Tamarix leptopetala replaces it and dominates over a wide area and 
is also dominant in many small dried rivulets and stream beds inside the area and this vegetation type is the most important vegetation type of the Iranian salt lands. This vegetation type shows a coverage of 50-75\% over the area. The most important companion species are Alhagi persarum Boiss. \& Buhse., Artemisia scoparia Waldst., Cressa cretica L., Cyperus rotundus L. Spergula fallax (Lwe.) E. H. L. Krause and Suaeda aegyptiaca (Hasselq.) Zoh. This vegetation type is situated in alluvial soils.

\section{2-Lycium edgworthii vegetation type (no. 12 in Fig. 3)}

Lycium edgworthii is distributed over certain parts of Iran. The vegetation type dominated by latter species is found on the margins of wet salty inland soils and also the external zone of the Mond River after the Tamarix-Phragmites vegetation type. Lycium edgworthii has a high density in some parts of the river margin. The coverage of this vegetation type varies between $60-70 \%$. The most important companion species of this vegetation type are Aloina aloides (Schultz) Kindb., Anagallis arvensis L., Bromus rubens L., Calendula persica C. A. Mey., Centaurium pulchellum (Swartz.) Druce., Cuscuta chinensis Lam., Lophochlora phleoides (Vill.) Reichenb., Phlaris minor Retz. This vegetation type occupies alluvial soils in the study area.

\section{3-Suaeda fruticosa vegetation type (no. 13 in Fig. 3)}

Suaeda fruticosa (L.) Forssk. is a dark green bushy plant which distributed across saline lands of the Sahara-Sindian region that in places penetrate into the Irano-Turanian region. This species is geographically distinct in central and southern saline (Zohary, 1973). The species is dominant in the vegetation type distributed over northern parts regions of the study area as well as Omolgorm, Tahmadoon and Nakhiloo Islands with alluvial soils. The coverage of this vegetation type varies between 75 and $100 \%$. The most important companion species of this type are Aeluropus lagopoides (L.) Trin. ex Thwaites, Cyperus rotundus L. Ephedra foliata Boiss and Kotschy., Lycium edgeworthi and Salsola drummondii Ulbrich.. Although this vegetation type shows some mixed situations with Lycium edgworthii vegetation type in some parts of the study area, there are many pure spots of this vegetation type dominated by Suaeda fruticosa in the area.

\section{B-bushy and grassland formations (vast inland area)}

\section{4,7- Halocnemum strobilaceum vegetation type (no. 4 \& 7 in Fig. 3)}

Halocnemum strobilaceum is a dwarf shrub or richly branched perennial herb turning dark green as an adult. This species is an penetrative element to coast lines and inland marshes. It occupies broad belts on the fringe of salt lakes and Kavirs with relatively higher water table (Akhani \& Ghorbanli, 1993). In Iranian inlands, it forms dense and almost pure stands for hundreds of miles around the smaller and large salt pans and also in «lost rivers» (Zohary, 1973). It also covers broad zones in the South and South west of Iran, extending far inwards from the seashores of the Persian Gulf, the Gulf of Oman and the Arabian Sea (Zohary, 1973). On the peripheries of most of the inland salines, it forms a pioneer halophytic community or the second phase after the Salicornia europaea vegetation (Zohary, 1973). The vegetation type dominated and characterized by Halocnemum strobilaceum is the largest vegetation type and distributed in almost all of inland parts of the study area with alluvial 
soils. The coverage of this type is $5-75 \%$. Due to the intensively salty conditions of the habitats of this vegetation type, companion species are very poorly represented. The most important companion species are Aelurupus lagopoides (L.) Trin. Ex Thwaites., Asphodelus tenuifolius Cav., Gynandriris sisyrinchium (L.) Parl., Plantago amplexicaulis Cav., Plantago coronopus L., Plantago psyliium L., Plantago stocksii Boiss. \& Decne., Psylliostachys spicata (Willd.), Sonchus tenerrimus L. and Suaeda heterophylla (Kar. et Kir.) Bge.

\section{6-Salsola drummundi vegetation type (no. 12 in Fig. 3)}

The genus Salsola comprises about 30 species in the Middle East. Except for a few annual and uncommon species, they are mostly dominant species in various plant communities (Zohary, 1973). Most Salsola species are xero-halophytes (Zohary, 1973). Salsola drummundi is the dominant species for the vegetation type distributed over the eastern parts of the study area with the Solonchak soils. The coverage of this vegetation type is $50-75 \%$. The most important companion species are Atriplex leucoclada (Boiss.) Aellen., Limonium iranicum (Bornm.) Lincz., Plantago psyliium L., Salsola cyclophylla Barker. and Suaeda aegyptiaca (Hasselq.) Zoh.

\section{7-Arthrocnemum macrastachyum vegetation type (no. 2 in Fig. 3)}

Arthrocnemum macrastachyum as a leafless, bushy succulent species with rather deep roots that is very common in the west over part the Middle East (Zohary, 1973). This species with the main distribution in Mediterranean region, occupies large stretches of littoral marshes (Akhani \& Ghorbanli, 1993). It penetrates however deeply into desert areas such as the Dead Sea area, inner Anatolia, the Syrian Desert and Iraq. In the coastal marshes of the East Mediterranean, this species forms large pure stands along the salt-water bodies. Arthrocnemum macrostachyum is distributed in northwestern, southern (Omolgorm Island) and southwestern (Tahmadoon and Nakhiloo Islands) areas. The Arthrocnemum macrostachyum vegetation type is unique to high salty and wet soils on the margins of salt lakes, banks and estuaries of high saline rivers and streams and of littoral marshes of the Persian Gulf. In other localities it is less exclusive but still very abundant (Zohary, 1973). The coverage of this vegetation type is $75-100 \%$ and it occurs on alluvial soils. Companion species are Atriplex leucoclada (Boiss.) Aellen, Cistanche tubulosa (Schrenk.) R. Wight., Halocnemum strobilaceum M. B., Limonium Iranicum (Bornm.) Lincz., Salicornia europaea L. and Suaeda heterophylla (Kar. et Kir.) Bge.

\section{8-Salicornia europaea-Suaeda heterophylla vegetation type (no. 14 in Fig. 3)}

Salicornia europaea and Suaeda heterophylla are two dominant annual species in this vegetation type distributed over the north west of the area. This vegetation type constitutes the first vegetation zone in salty habitats near maritime and estuary areas with Solenchak soils. The coverage of this type is $75-100 \%$. Companion species of this vegetation type are Arthrocnemum macrastachyum and Halocnemum strobilaceum. This vegetation type was previously considered to be one of the obligatory hygro-halophtic communities in the classification presented by Akhani and Ghorbanli (1993).

\section{9-Cyperus conglomeratus-Halopyrum mucronatum vegetation type (no. 10 in Fig. 3)}

Cyperus conglomeratus and Halopyrum mucronatum are dominant species of this vegetation type which is located on the coastal shores to the south east of the study area 
with coverage of $25-50 \%$. The most important companion species are Atriplex leucoclada (Boiss.) Aellen., Cistanche tubulosa (Schrenk.) R. Wight., Heliotropium bacciferum Forssk., Salsola jordanicola Eig., Senecio vulgaris L. and Helianthemum lippi (L.) Pers. This vegetation type is found in alluvial or sandy soils.

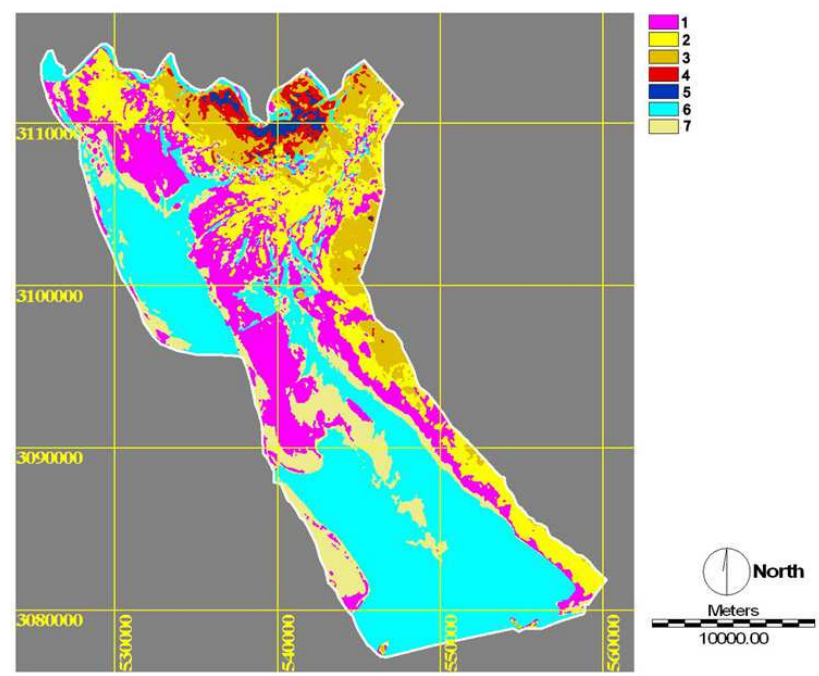

Fig. 4. Vegetation density map of the Mond Protected Area (1=very scanty, 2=scanty, $3=$ semi-scanty, $4=$ low dense, $5=$ dense, $6=$ water, $7=$ bare land)

\section{0- Atriplex leucoclada vegetation type (no. 11 in Fig. 3)}

The genus Atriplex is represented by the number of dominant species in various vegetation types of which some species (e.g. A. halimus and A. leucoclada) are distributed in salty habitats (Zohary, 1973). The Atriplex leucoclada vegetation type is distributed on Nakhiloo Island (south west part). The coverage of this vegetation type is 50-75\%. The most important companion species are Aizoon canarensis L., Cornulaca aucheri, Heliotropium bacciferum Forssk., Spergularia marina (L.) Griseb., Polycarpon tetraphyllum (L.) L. and Senecio vulgaris $L$. This vegetation type occupies sandy soils.

\section{1-Ephedra foliata vegetation type (no. 6 in Fig. 3)}

Ephedra is an excellent example of a world-wide genus represented in the Middle East by about ten species (Zohary, 1973). The Ephedra foliata is a Sudanian element in the Middle East and confined to the Gulf of Eilat, southern Arabia and southern Iran (Zohary, 1973). Ephedra foliata vegetation type is distributed only on Omolgorm Island, and over very small patches in northern parts of the area. The coverage of this type is $25-50 \%$. The companion species are Cyperus conglomerates Rottb., Senecio vulgaris L. and Suaeda fruticosa (L.) Forssk. This vegetation type occupies sandy soils in the study area. 


\section{C-Mangrove forest formations (coastal vegetation)}

\section{2-Avicennia marina vegetation type (mangrove forest) (no. 9 in Fig. 3)}

Mangrove forests are sensitive habitats due to their ecotonic (transitional) condition, i.e. they are affected by both marine and land ecosystems. These forests are confined to shores of the Persian Gulf (including its islands) and Oman Sea in the Middle East. The Avicennia marina vegetation type in Mond protected area is the furthest western range of Mangrove distribution in the world. Avicennia marina is the typical component of this vegetation, a species belonging to eastern mangroves that are distributed broadly in throughout world (Zohary, 1973). This vegetation type is somewhat mixed with other vegetation types, e.g. Arthrocnemum macrastachyum and Halocnemum strobilaceum vegetation types. The coverage of this type is $50-100 \%$. It occupies alluvial and Solenchak soils in the area. Other companion species of this vegetation type are Arthrocnemum macrastachyum, Cistanche tubulosa (Schrenk) R. Wight and Salicornia europaea.

\section{D-vegetation affected by human activities (anthropogenic effects)}

\section{3-Suaeda aegyptiaca vegetation type in abandoned farmlands (no. 1 in Fig. 3)}

There are about 22 species of this genus in the Middle East, of which only a few are important for their broad distribution. They can be divided into hydro- and xero-halophytes and occur in both littoral and inland saline habitats. Suaeda aegyptiaca is a ruderal species and therefore the vegetation type dominated by this species establishes in abandoned farmlands. This vegetation type with coverage of 50-75\% occurs mainly in northern parts of the area with alluvial soils. The companion species includes Artemisia scoparia Waldst. \& Kit., Atriplex leucoclada, Calendula persica C. A. Mey., Chrozophora hierosolymitana Spreng., Senecio vulgaris L., Sonchus oleraceus L., Sporobolus arabicus Boiss. and Stellaria media (L.) Cyr.

\section{4-Farmlands (anthropogenic vegetation) (no. 5 in Fig. 3)}

One of the important categories in the vegetation map prepared is farmlands representing areas strongly affected by man and livestock. This map category is largely the result of human agricultural activity, and is comprised of three large units, namely cultivated, segetal and ruderal (Zohary, 1973). This map unit is distributed over the margins of the northeastern and eastern parts with alluvial and Solenchak soils.

E-Map units without vegetation

\section{5-Bare lands (no. 3 in Fig. 3)}

Bare lands constitute one of the largest units in the vegetation map of the study area located along the coastal line. Due to high salinity, vegetation density was as low as nearly 0 . This vegetation type is established in Solenchak soils.

\section{6-Water (no. 8 in Fig. 3)}

The eastern and southern parts of the study area are fully occupied by water connected to the Sea (Fig. 3). 


\section{Conclusion}

The current study is a new approach to vegetation mapping in Iran using remote sensing (RS) and the geographic information system (GIS). One of the most important problems in remote sensing of desert vegetation is that the reflectance from soil and rocks is often much greater than that of sparse vegetation and this makes it difficult to separate out the vegetation signal (Gates et al. 1965); and there is spectral variability within shrubs of the same species (Duncant et al., 1993). These properties hamper accurate classification of vegetation in these areas. This study proved the usefulness of the Spot XS imagery for vegetation mapping but also it showed that in arid regions, mapping can only be completed satisfactorily if it is accompanied by extensive field sampling, visual image interpretation and hybrid classification methods. Thus, hybrid approaches that include field work, GIS and RS are required in such circumstances.

In a study of the halophytic vegetation of the Middle East, Zohary (1973) discussed that the most halophytic communities of Iran belong to the phytosociological classes Halocnemum strobilacei irano-anatolica. Breckle (1983) classified the halophytic vegetation of Iran and Afghanistan as follows: (1) saline flats (very sparse vegetation, soil with very high salt content); (2) euhalophytic vegetation (halo-hammada on gravel-sandy but probably clay soil) and (3) mesohalophytic vegetation (with less salt in the soil profile). Frey and Probst (1986) provided a geographical classification for total halophyte vegetation including (1) salty pans of the central Iranian undrained basin and their peripheries; (2) shore zones of salt lakes; (3) areas the Persian Gulf and (4) southern Caspian coastal zone. Akhani and Ghorbanli (1993) with a geographical-ecological approach classified halophytic communities of Iran as (1) Halocnemum strobilaceum communities (on muddy salt flats); (2) obligatory hydro-halophytes communities; (3) Tamarix communities; (4) Hydrophilous euryhlophytic communities; (5) Mangrove communities; (6) Hydrohalophytic plant communities; (7) Halophytic shrub communities on salty and dry soils; (8) Herbaceous perennial and hemicryptophyte halophytic communities; (9) xeromorphytic communities with salt-tolerant xerophytes and (10) annual halophytic communities.

Mond Protected Area is one of the best indicators of halophytic vegetation in the arid lands of Iran. Salty river, salty pans, coastal and muddy salt flats induce habitat diversity supporting the establishment of different halophytic vegetation types (see Figs. 2, 3, 4). This study identified 15 map units of which 12 are concerned with vegetation types. These vegetation types reveal plant communities adapted to different habitats and environmental gradients in the area.

Most vegetation types identified in the current study were previousy recognized in the other arid or salty areas of Iran (Akhani and Ghorbanli, 1993; Asri \& Ghorbanli, 1997; Ghahreman et al., 2000; Alaei et al. 2001). The occurrence of Halocnemum strobilaceum, Avicennia marina, Salicornia europaea-Suaeda heterophylla, Suaeda fruticosa, Tamarix leptopetala and Arthrocnemum macrostachyum vegetation types is identical with the results of Akhani and Ghorbanli (1993). The study area can be considered as the first and third vegetation zones defined in the classification offered by Breckle (1983). This research revealed that the establishment of the vegetation types is largely regulated by edaphic factors (texture, chemical composition and humidity). Some parts of the area are impacted by agricultural activity, grazing and the destruction of vegetation. These activities have led to major changes in habitats and ecosystems and have threatened wildlife. These ecosystems represent landscapes that can be restored and managed for uses such as ecotourism and recreation. 


\begin{tabular}{lll}
\hline Vegetation types & Surface (ha) & Percentage (\%) \\
\hline Halocnemum stroboilaceum & 19320.1 & 36.30 \\
Suaeda aegyptica & 3044.52 & 5.72 \\
Salsola drummondii & 1080.88 & 2.03 \\
Lycium edgworthii & 708.72 & 1.33 \\
Suaeda fruticosa & 263.96 & 0.50 \\
Arthrocnemum macrastachyum & 209.52 & 0.39 \\
Tamarix leptopetala & 189.04 & 0.36 \\
Cyperus conglomerates- & 87.04 & 0.16 \\
Halopyrum mucronatum & 18.92 & 0.04 \\
Atriplex leucoclada & 14.56 & 0.03 \\
Avicennia marina & 8.92 & 0.02 \\
Ephedra foliata & 9 & 0.02 \\
Salicorniaeuropaea-suaeda & 9855.12 & 12.88 \\
teterophylla & 53227 & 100.00 \\
Farmalnds & 364.52 & 0.68 \\
Water & 21052.2 & 39.55 \\
Bare lands & 685 \\
Total & & \\
\hline
\end{tabular}

Table 1. Areal coverage of vegetation types in the Mond Protected Area

\section{References}

Akhani. H., Ghorbanli M. (1993). A contribution to the halophytic vegetation and flora of Iran, in H. Leith and A. Al- Masoom (eds.). Towards the Rational use of High Salinity Tolerant Plants, vol. 1, p. 35-44, Kluwer Academic publishers, Netherlands.

Archibold, O. W. (1995). Ecology of World vegetation. London. Chapman \& Hall. 1-510.

Asri Y., Ghorbanli M. (1997). The halophilous vegetation of the Orumieh lake salt marshes, NW. Iran. Plant Ecology 132, 155-170.

Asri Y., Hamzehee B., Ghorbanli M. (1995). Etude Phytosociologique de la vegetation halophile de l'est du lac Orumieh (Nord Ouest de l'Iran). Doc. Phytosociology, 15: 299-308.

Assadi M. (1984). Studies on the autumn plants of Kavir, Iran. Iran. j. Bot. 2, 125-148.

Attar F., Hamzehée B, Ghahreman A (2004). A Contribution to flora of Qeshm Hsland, Iran. Iran. J. Bot. 10, 199-218.

Balvenera, P., Daily, G., Ehrlich, P., Ricketts, T., Bailey, S., Kark, S., Kermen, C. \& Pereira, H (2001). Conserving biodiversity and ecosystem services. Sciences, 291, 2047. 
Braun-Blanquet J. (1964). Pflanzensoziologie: Grundzüge der Vegetationskunde. 3. neu bearb. Aufl. - Springer-Verlag. Wien.

Breckle S.W. (1983). Temperate deserts and semi-deserts of Afghanistan and Iran. In: N. E. West (ed). Ecosystems of the World. 5 : Temperate Deserts and Semi-Deserts. Elsevier. Amsterdam. 271-319.

Calarck P.E., Seyfried M.S., Harris B. (2001). Intermountain plant community classification using Landsat TM and spot HRV data. Range Management 54, 152-160.

Carle R., Frey W. (1977). Die vegetation des Maharlu-Beckenis bei Shiraz (Iran) Unter besonderer beruccksichitigung der vegetation im bereich der suss-und salzawasserquellen am seeufer. Beih. TAVO, Reihe A (Naturwiss) 2, Dr. Ludwig Reuchert Verlag, Wiesbaden.

Dewan M., Famouri J. (1964). The Soils of Iran. FAO, Rome.

Duncant J., Stow D., Franklin J., Hope A. (1993). Assessing the relationship between spectral vegetation indices and shrub cover in the Jourdan Basin, New Mexico. International journal of Remote Sensing, 14, 3395-3416.

Frey W., Probst W. (1986). A synopsis of the vegetation of Iran. In : H Kürschner (ed). Contribution of the vegetation of southwest Asia. Beih. TAVO. Naturwiss, 24, 9-24.

Frey W. (1982). Maharlu-Becken bei Shiraz (Iran). Mittlerer Teil. Vegetation, 1: 100,000, Karte AVI 10.2 TAVO, Dr. Ludwig Reichert Verlag, Wiesbaden.

Freitag H. (1977). Turan Biospher Reserve, prelimnary vegetation map, pp. 86-89. im : Spooner, B. (ed.). Case Study on Desertification Iran : Turan. Department of Environment, Tehran.

Gates D.M., Keegan H.J., Schleter J.C., Weidner V.R. (1965). Spectral properties of plants. Applied Optics, 4, 11-20.

Ghahreman A., Hamzehée B., Attar F. (2000). Natural Vegetation Map of the Qeshm island, Publication of Qeshm Free Area.

Ghorbanli M., Lambinon J. (1978). Permier. Apereu de la zonation de la vegetation halogypsophile du lac Ghom. Lenjunia Rev. Bot. $92: 1-20$.

Hamzehée B. (2001). Application of Anaphyto Software in Phytosociological data analysis (A Case Study: Eroded Terraces of the Queshm Island). - Research Institute of Forests and Rangelands. Tech. Publ. 237. Tehran. 379 pp. (In Persian).

Jensen, J. R. (1996). Introductory Digital Image Processing. A Remote Sensing Perspective (2nd ed). New Jersey : Prentice Hall.

Kramer W. (1984). Mittleter Zagros (Iran) Vegetation, 1:600,000, Karte AVI 6 TAVO, Dr. Ludwig Riechert Verlag, Wiesbaden.

Kunkel G. (1977). The vegetation of Hormoz, Qeshm and neighboring islands (Persian Gulf area). Flora et vegetatio Mundi 6. 186p.

Leica Geosystems Geospatial Imaging (2002). Erdas Imagine 8.4 software, USA.

Leonard J. (1981-1988). Contribution a l'étude de la flore et de la végétation des déserts d Iran. Fasc 1-9. Meise.

McGraw J.F., Tueller P.T. (1983). Landsat computer-aided analysis teqniques for range vegetation mapping. Journal of Range Managements, 36: 627-631.

Mehrabin A. R., Naqinezhad A., Mostafavi H., Kiabi B., Abdoli A. Flora and habitats of Mond Protected area. Mohit Shenasi., Vol 46(1) : 1-18

Mobayen S. (1976). Structure geobotanique du Lut. Acta Ecol. Iranica 1, 73-86. 
Mobayen S., Tregubov V. (1970). Carte de la végétation naturelle de 1,Iran, 1; 250,000. University Tehran, UNDP/FAO no.Ira 7.

Rechinger K.H. (ed.) (1963-1999). Flora Iranica. Vien, Graz : Akademische Druck.

Salman Mahiny A. ( 2004). A Modelling Approach to Cumulative Effects Assessment for Rehabilitation of Remnant Vegetation. Ph.D. Thesis, ANU, Australia.

Omar. Samir. A. S., Misak. R., King. P., Shahid. Shabbir. A., Abo-Rizk. Hanna, Grealish. G. and Roy. W. (2001) Mapping the vegetation of Kuwait through reconnaissance soil survey. Journal of Arid Environment, 48: 341-355.

Termeh F., Moussavi M. (1976). Contribution a l'étude de la végétation automnale du Dashte-Lut. Institut de Recherches Entomologiques et Phytopathologiques d Evine, Department of Botany. Tehran. No. 7.

Termeh F., Moussavi M. (1982). Plants of Kish Island, Iran. Wildenowia, 12, 253-286.

Tobler M.W., Cochard R., Edward P.J. (2003). The impact of cattle ranching on large-scale vegetation patterns in coastal Savanna in Tanzannia. journal of Applied ecology, 30, 430-444.

Wallens J., Milington A.C., Hichkin W., Arquepino R., Jones S. (2000). Mapping humid tropical vegetation in eastern Bolivia in R. Alexander and A. C. Millington (Eds) Vegetation Mapping. Chichester : John Willey and sons.

Zak M.R., Cabido M. (2002). Spatial pattern of the Chaco vegetation of central Argentina. Integration of remote sensing and phytosociology. Applied Vegetation Sciences, 5, $213-226$.

Zarrin-kafche M. (1977). Etude de la relation existent entre la compositon chemique des plants et celle des Sols du Sud de karadj (pressé de Tehran). Acta Ecology. Iran. 1, 60-69.

Zohary M. (1963). On the Geobotanical Structure of Iran. Bull. Res. Counc. Isr., Sect. d, Bot., Suppl. 1. 113p.

Zohary M. (1966-1986). Flora Palestine, Vol : 1-4. The Israel Academy of Sciences and Humanities.

Zohary M. (1973). Geobotanical Foundations of the Middle East. 2 vols. Gustav Fischer Verlag. Amesterdam. 


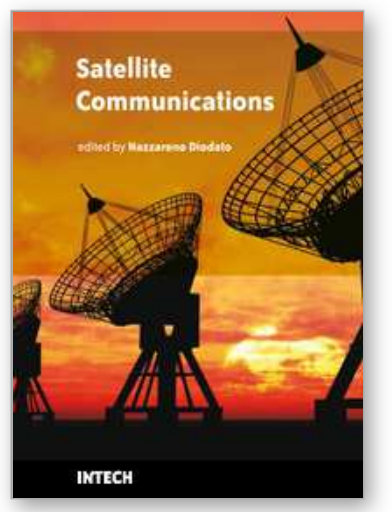

\author{
Satellite Communications \\ Edited by Nazzareno Diodato
}

ISBN 978-953-307-135-0

Hard cover, 530 pages

Publisher Sciyo

Published online 18, August, 2010

Published in print edition August, 2010

This study is motivated by the need to give the reader a broad view of the developments, key concepts, and technologies related to information society evolution, with a focus on the wireless communications and geoinformation technologies and their role in the environment. Giving perspective, it aims at assisting people active in the industry, the public sector, and Earth science fields as well, by providing a base for their continued work and thinking.

\title{
How to reference
}

In order to correctly reference this scholarly work, feel free to copy and paste the following:

Ahmadreza Mehrabian, Abdolrassoul Salman Mahiny, Hossein Mostafavi and Homan Liaghati (2010). Vegetation Mapping of the Mond Protected Area of Bushehr Provice (SW Iran), Satellite Communications, Nazzareno Diodato (Ed.), ISBN: 978-953-307-135-0, InTech, Available from:

http://www.intechopen.com/books/satellite-communications/vegetation-mapping-and-ecological-management

\section{INTECH}

open science | open minds

\section{InTech Europe}

University Campus STeP Ri

Slavka Krautzeka 83/A

51000 Rijeka, Croatia

Phone: +385 (51) 770447

Fax: +385 (51) 686166

www.intechopen.com

\section{InTech China}

Unit 405, Office Block, Hotel Equatorial Shanghai

No.65, Yan An Road (West), Shanghai, 200040, China

中国上海市延安西路65号上海国际贵都大饭店办公楼 405 单元

Phone: +86-21-62489820

Fax: $+86-21-62489821$ 
(C) 2010 The Author(s). Licensee IntechOpen. This chapter is distributed under the terms of the Creative Commons Attribution-NonCommercialShareAlike-3.0 License, which permits use, distribution and reproduction for non-commercial purposes, provided the original is properly cited and derivative works building on this content are distributed under the same license. 